\title{
Amino-Terminal Amino Acid
}

National Cancer Institute

\section{Source}

National Cancer Institute. Amino-Terminal Amino Acid. NCI Thesaurus. Code C54120.

The amino acid residing in the first position of a protein or peptide. 